\title{
Effect of Morphology and Dispersibility of Silica Nanoparticles on the Mechanical Behaviour of Cement Mortar
}

\author{
Lok Pratap Singh $^{1), *}$, Anjali Goel ${ }^{2)}$, Sriman Kumar Bhattachharyya ${ }^{1)}$, Saurabh Ahalawat ${ }^{1)}$, \\ Usha Sharma', and Geetika Mishra ${ }^{1)}$
}

(Received June 20, 2014, Accepted February 3, 2015, Published online February 28, 2015)

\begin{abstract}
The influence of powdered and colloidal nano-silica (NS) on the mechanical properties of cement mortar has been investigated. Powdered-NS $(\sim 40 \mathrm{~nm})$ was synthesized by employing the sol-gel method and compared with commercially available colloidal NS ( $20 \mathrm{~nm})$. SEM and XRD studies revealed that the powdered-NS is non-agglomerated and amorphous, while colloidal-NS is agglomerated in nature. Further, these nanoparticles were incorporated into cement mortar for evaluating compressive strength, gel/space ratio, portlandite quantification, C-S-H quantification and chloride diffusion. Approximately, 27 and $37 \%$ enhancement in compressive strength was observed using colloidal and powdered-NS, respectively, whereas the same was up to $19 \%$ only when silica fume was used. Gel/space ratio was also determined on the basis of degree of hydration of cement mortar and it increases linearly with the compressive strength. Furthermore, DTG results revealed that lime consumption capacity of powdered-NS is significantly higher than colloidal-NS, which results in the formation of additional calcium-silicate-hydrate (C$\mathrm{S}-\mathrm{H})$. Chloride penetration studies revealed that the powdered-NS significantly reduces the ingress of chloride ion as the microstructure is considerably improved by incorporating into cement mortar.
\end{abstract}

Keywords: cement mortar, nano-silica, strength, morphology, dispersibility.

\section{Introduction}

Use of nanomaterials in the construction sector is gaining widespread attention as significant improvements are expected to be achieved in the desired properties of construction materials. The most commonly used nanomaterials in the cement are nano-silica, nano-titania, nano-alumina, carbon nano-tubes (CNTs) etc. (Sanchez and Sobolev 2010). Among all, nano-silica has been proven an effective additive to cement matrix for accelerating cement hydration due to its high reactivity, ability to refine the microstructure and thus, leading to a reduced porosity (Toutanji et al. 2004). Various types of nano-silica (powder or in suspension) are available commercially, having specific density, specific surface area, pore structure and reactivity (Quercia et al. 2014). Several researchers (as reviewed by Singh et al. (2013)) reported that the mechanical properties and durability can be improved by adding nano-silica (powder or colloidal) in cement-based materials. The enhancement in compressive strength of cement mortar with $0.25 \%$ powder nano-silica was achieved 63.9 and $95.9 \mathrm{MPa}$ at the age of 1 and 28 days, respectively

\footnotetext{
${ }^{1)}$ CSIR-Central Building Research Institute, Roorkee 247 667, India.

*Corresponding Author; E-mail: lpsingh@cbri.res.in

${ }^{2)}$ Gurukul Kangri University, Haridwar 249404, India.

Copyright $($ The Author(s) 2015. This article is published with open access at Springerlink.com
}

(Flores 2010). The characteristics of cement mortar with powder nano-silica particles showed that nano-silica behaves not only as a filler to improve the microstructure but also as an activator to promote the pozzolanic reaction (Jo et al. 2007). The performance enhancing properties of nano-silica are achieved through two mechanisms: firstly, the ultrafine particles are able to fill the voids between the cement particles improving "packing" and creating a less permeable structure. Secondly, the nano-silica also reacts with the calcium hydroxide $(\mathrm{CH})$ produced with the cement hydration to form additional C-S-H (Gaitero et al. 2008, 2009). The porosity and capillary pores decreased while the gel pores increased as a result of the inclusion of silica fume and fly ash in the cement-based composites (Lin et al. 2009). Several researchers (as reviewed by Shi et al. (2012)) have studied the role of mineral admixtures in concrete durability, methods of measuring chloride ingress into concrete, challenges in assessing concrete durability from its chloride diffusivity, and the service life modeling of reinforced concrete in chloride-laden environments. The ingress of gases, water or ions in aqueous solutions into concrete takes place through pore spaces in the cement paste matrix and pasteaggregate interfaces or microcracks. For the durability of concrete, permeability is believed to be the most important characteristic (Baykal 2000), related to its microstructural properties, such as the size, distribution, and interconnection of pores and microcracks (Savas 2000). The water permeability test shows that the nano-silica concrete has lower water permeability as compared to normal concrete (Ji 2005). 
The incorporation of nanoparticles $\left(\mathrm{Fe}_{2} \mathrm{O}_{3}, \mathrm{Al}_{2} \mathrm{O}_{3}, \mathrm{TiO}_{2}\right.$ and $\mathrm{SiO}_{2}$ ) and nanoclays (montmorillonite) reduces the diffusion coefficient of the mortar as well as electrochemical impedance spectroscopy. The tests indicate that such effects are especially significant using nano- $\mathrm{SiO}_{2}$ and nanoclays (He and Shi 2008).

In contrast, colloidal nano-silica (CNS) denotes small particles (1-100 nm) consisting of an amorphous silica core with a hydroxylated surface, which are insoluble in water (Coenen and Kruif 1988). The accelerating effects of colloidal silica on $\mathrm{C}_{3} \mathrm{~S}$ phase dissolution; $\mathrm{C}-\mathrm{S}-\mathrm{H}$ gel formation and silica polymerisation in cement paste hydration were studied (Bjornström et al. 2004). The surface treatment of colloidal nano-silica was found effective in decreasing water absorption of cement mortar at $50{ }^{\circ} \mathrm{C}$, but a negligible effect at $20{ }^{\circ} \mathrm{C}$ and filled coarser pores (>50 nm) (Hou et al. 2014). The addition of $6 \%$ CNS improves the compressive strength of mortar from 18.3 to $46.3 \mathrm{MPa}$, at 7 days (Jo et al. 2007). The improvements are attributed to three reasons: the acceleration effect of CNS on cement hydration, pozzolanic reaction of CNS and the improved particle packing of matrix. Cement with 2-4\% addition of CNS do not lead to an immediate mechanical strength gain due to the formation of agglomerates, later on hydration evolution takes place due to consumption of calcium hydroxide (Kontoleontos et al. 2012).

Nano-silica is extensively used in cement matrix, though their mixing is a challenge which needs to be addressed. When nanoparticles are added into the cement with water, they form agglomerates and may not reflect its original reactivity (Kong et al. 2013). In order to address this issue (i.e. homogeneous mixing of nanomaterials) dispersible silica nanoparticles were prepared and introduced into cement mortar. Further, the experiment comprises the comparison of powdered and colloidal NS with respect to their effect on gel/space ratio, compressive strength, pozzolanic reactivity of both nano-silica and silica fume and quantification of the $\mathrm{C}-\mathrm{S}-\mathrm{H}$ using thermogravimetric analysis were conducted. Moreover, chloride penetration of plain and nanomodified cement mortar was investigated.

\section{Experimental Protocols}

\subsection{Materials}

The present study was carried out with 43 grade OPC, type I cement, conforming to IS: 8112 . The cement was analyzed for various proportions as per IS 4031-1988. Standard sand of grade (I, II and III) was chosen according to IS: 650 . Grade I type sand consists course aggregate with particles size 1-2 mm, grade II consists fine aggregates with particles size $0.5-1 \mathrm{~mm}$ and grade III comprises very fine aggregates with particle size ranges between 0.09 to $0.5 \mathrm{~mm}$. This sand attained a fineness modulus of 2.86 and a saturated surface dry specific gravity of 2.59 . A high quality commercial grade silica fume (M/s Elkem) was used. The physical and chemical properties of the cement and silica fume are given in Table 1.
Further, two different type of nano-silica namely powder nano-silica $(\sim 40 \mathrm{~nm})$ prepared in laboratory using sodium silicate as precursor and colloidal nano-silica $(15-20 \mathrm{~nm})$ was commercially available as an aqueous dispersion having the $\mathrm{pH}$ value of 9.2, and $\mathrm{SiO}_{2}$ content (by weight) of $30 \%$ corresponds to a density of $1.28 \mathrm{~g} / \mathrm{mL}$. The specific surface area of colloidal-NS is in the range of $170-200 \mathrm{~m}^{2} / \mathrm{g}$. For introducing nano-silica into cement mortar ultrasonic treatment was used to disperse the agglomerates. In this method nano-silica and water were sonicated for $30 \mathrm{~min}$ at $42 \mathrm{kHz}$ frequency and 80 watt absorbed power using a $2.5 \mathrm{~L}$ capacity bath sonicator till the solution turned milky. Afterwards, this sonicated mixture was mixed for $1 \mathrm{~min}$ with cement and sand in the Hobart mixer having B-type blade. Mortar mixer as per the standard ASTM C144 was used for mortar preparation. The mixer was equipped with B- flat type peddles, having minimum and maximum revolution speed of $140 \pm 5 \mathrm{rpm}$ and $285 \pm 10 \mathrm{rpm}$, respectively. The capacity of the bowl was $\sim 5 \mathrm{~L}$.

\subsection{Methodology \\ 2.2.1 Preparation of Silica Nanoparticles: Sol Gel} Method

For the cost-effective preparation of nano-silica, sol-gel technique was followed using sodium silicate as a precursor (Tan et al. 2005; Venkatathri and Nanjundan 2009). In this preparation cetrimonium bromide (CTABr) as dispersing agent and $1 \mathrm{~N} \mathrm{HCl}$ as catalyst was used. CTABr, $\mathrm{HCl}$ and deionized water were mixed, stirred for $45 \mathrm{~min}$, followed by dropwise addition of $1 \mathrm{M}$ solution of sodium silicate with stirring at room temperature until the $\mathrm{pH}$ of reaction system reached $\sim 8.0$. The resultant white suspension was filtered and washed with deionized water to remove all the sodium chloride formed (Fig. 1). The prepared powder was dried $\left(50^{\circ} \mathrm{C}\right)$ and then muffled at $700{ }^{\circ} \mathrm{C}$ for $4 \mathrm{~h}$ (Singh et al. 2012a, b). Finally, the white powder was characterized by scanning electron microscope (SEM), X-ray diffraction (XRD), BET techniques. The morphological attributes of two types of nano-silica and mortar samples containing nano-silica and silica fume were studied using SEM (LEO 438VP) at an accelerating voltage of $15-20 \mathrm{kV}$. The samples were analysed under variable pressure (VP) mode with gold coating so as to improve the surface conductivity. For SEM analysis, the slices of the mortar samples were cut directly and immersed in acetone to discontinue the hydration process. The dried samples were deposited on a sample holder with a double stick conducting carbon tape to develop their micrographs. For XRD studies, Rigaku make (DMax-2200) with a X-ray source of $\mathrm{Cu} \mathrm{K} \alpha$ radiation $(\lambda=1.54 \AA)$ was used. The powder sample of 75 micron sieved was used for analysis. The scan step size was $0.02^{\circ}$, in $2 \theta$ range from 5 to $80^{\circ}$. The X-ray tube voltage and current were fixed at $40 \mathrm{kV}$ and $40 \mathrm{~mA}$, respectively. The specific surface area of powder nano-silica was analyzed with BET (model Adsotrac DN-04, Microtrac SSA, USA). 
Table 1 Chemical composition of OPC and silica fume used.

\begin{tabular}{c|c|c}
\hline Parameters & OPC & Silica fume \\
\hline $\mathrm{SiO}_{2}(\%)$ & 22.1 & 06.03 \\
\hline $\mathrm{Al}_{2} \mathrm{O}_{3}(\%)$ & 6.8 & 0.43 \\
\hline $\mathrm{Fe}_{2} \mathrm{O}_{3}(\%)$ & 2.2 & 0.25 \\
\hline $\mathrm{CaO}(\%)$ & 61.6 & 0.63 \\
\hline $\mathrm{MgO}(\%)$ & 3.4 & 0.30 \\
\hline $\mathrm{SO}_{3}(\%)$ & 2.4 & 0.40 \\
\hline $\mathrm{Na}_{2} \mathrm{O}(\%)$ & 0.12 & 0.63 \\
\hline $\mathrm{K}_{2} \mathrm{O}(\%)$ & 0.7 & $0.1-10 \mu \mathrm{m}$ \\
\hline Average diameter $(\mathrm{nm})$ & - & 2.23 \\
\hline Specific gravity & 3.15 & 29 \\
\hline Specific surface area $\left(\mathrm{m}^{2} / \mathrm{g}\right)$ & - & 1.98 \\
\hline LOI & 0.5 & \\
\hline
\end{tabular}

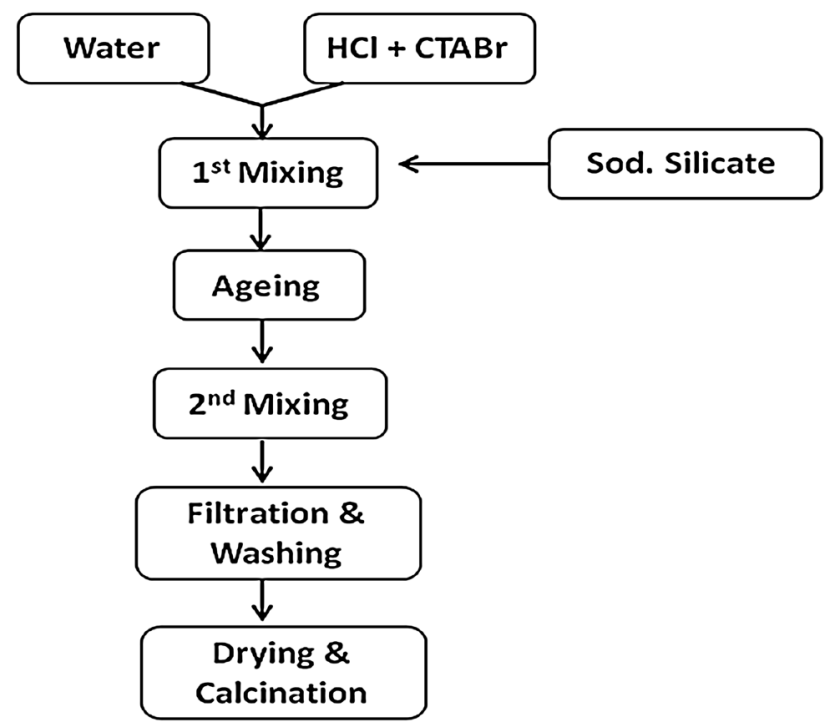

Fig. 1 Synthesis flow chart.

\subsubsection{Compressive Strength}

Standard cube molds $(50 \times 50 \times 50 \mathrm{~mm})$ were used to prepare mortar specimens for compressive strength determination. The mix proportions of cement and sand in mortar was 1:3 throughout. The water-to-cement ratio for all the samples was fixed at 0.4 . The nano-silica addition was 1.0 , 2.0 and $3.0 \%$ by weight of cement. Water content in colloidal-NS was considered in the mix proportion calculation. The cubes were de-moulded after curing at $20 \pm 1{ }^{\circ} \mathrm{C}$ and over $95 \%$ of relative humidity for $24 \mathrm{~h}$ followed by immersing in water at $20 \pm 1{ }^{\circ} \mathrm{C}$ till the testing time. Three specimens were used to determine the average compressive strength.

2.2.3 Quantification of Portlandite (CH) and C-SH Through Thermo-gravimetric Analysis (TG/DTG)

$\mathrm{CH}$ content of mortars with and without NS addition was detected using thermo-gravimetric method. The procedure follows the heating of powdered sample from 50 to $1000{ }^{\circ} \mathrm{C}$ at the rate of $10{ }^{\circ} \mathrm{C} \mathrm{min}{ }^{-1}$ in a Perkin-Elmer thermogravimetric analyzer. Before the tests, at desired hydration time samples were crushed and dipped into acetone to stop hydration for $24 \mathrm{~h}$. Further, the powdered samples were dried at $105{ }^{\circ} \mathrm{C}$ for $4 \mathrm{~h}$. In the DTG curve, the weight loss between $400-500{ }^{\circ} \mathrm{C}$ was recorded and considered as the cause of $\mathrm{CH}$ decomposition (Singh et al. 2012a, b; Jain and Neithalath 2009). The temperature range of mass loss between $110^{\circ} \mathrm{C}$ and the temperature at which $\mathrm{CH}$ loss begins $\left(400{ }^{\circ} \mathrm{C}\right)$ is considered to indicate the loss of water from $\mathrm{C}-$ S-H gel (Ramachandran et al. 2003; Gallucci et al. 2013; Olsona and Jennings 2001). The amount of $\mathrm{CH}(\%)$ and $\mathrm{C}-$ $\mathrm{S}-\mathrm{H}(\%)$ in the sample is calculated from the TG curves using the following Eqs. (1 \& 2):

$$
\begin{aligned}
& \mathrm{CH}(\%)=\mathrm{WL} \%(\mathrm{CH}) \times \frac{\mathrm{MW}(\mathrm{CH})}{\mathrm{MW}(\mathrm{H})} \\
& \mathrm{CSH}(\%)=\mathrm{WL} \%(\mathrm{CSH}) \times \frac{\mathrm{MW}(\mathrm{CSH})}{\text { Moles of water } \times \mathrm{MW}(\mathrm{H})}
\end{aligned}
$$

where $\mathrm{WL} \%(\mathrm{CH}) \& \mathrm{WL} \%(\mathrm{CSH})$ correspond to the mass loss in percentage attributable to $\mathrm{CH}$ and $\mathrm{C}-\mathrm{S}-\mathrm{H}$ dehydration, and $\mathrm{MW}(\mathrm{CH}), \mathrm{MW}(\mathrm{CSH})$ and $\mathrm{MW}(\mathrm{H})$ are the molecular weights of $\mathrm{CH}, \mathrm{C}-\mathrm{S}-\mathrm{H}$ and water, respectively.

\subsubsection{Chloride Penetration Resistance}

An accelerated electromigration test was performed on glass cell assembly for measuring chloride ion movement (Fig. 2). Plain and nanomodified cement mortar was shaped into disc of $7 \mathrm{~mm}$ thickness and $30 \mathrm{~mm}$ in diameter and stored for $24 \mathrm{~h}$ at $20{ }^{\circ} \mathrm{C}$. The specimens were de-moulded after $24 \mathrm{~h}$ and then cured in distilled water at room temperature $\left(20 \pm 1{ }^{\circ} \mathrm{C}\right)$. Further, these disc shaped mortar specimens after 28 days of hydration were sandwiched 


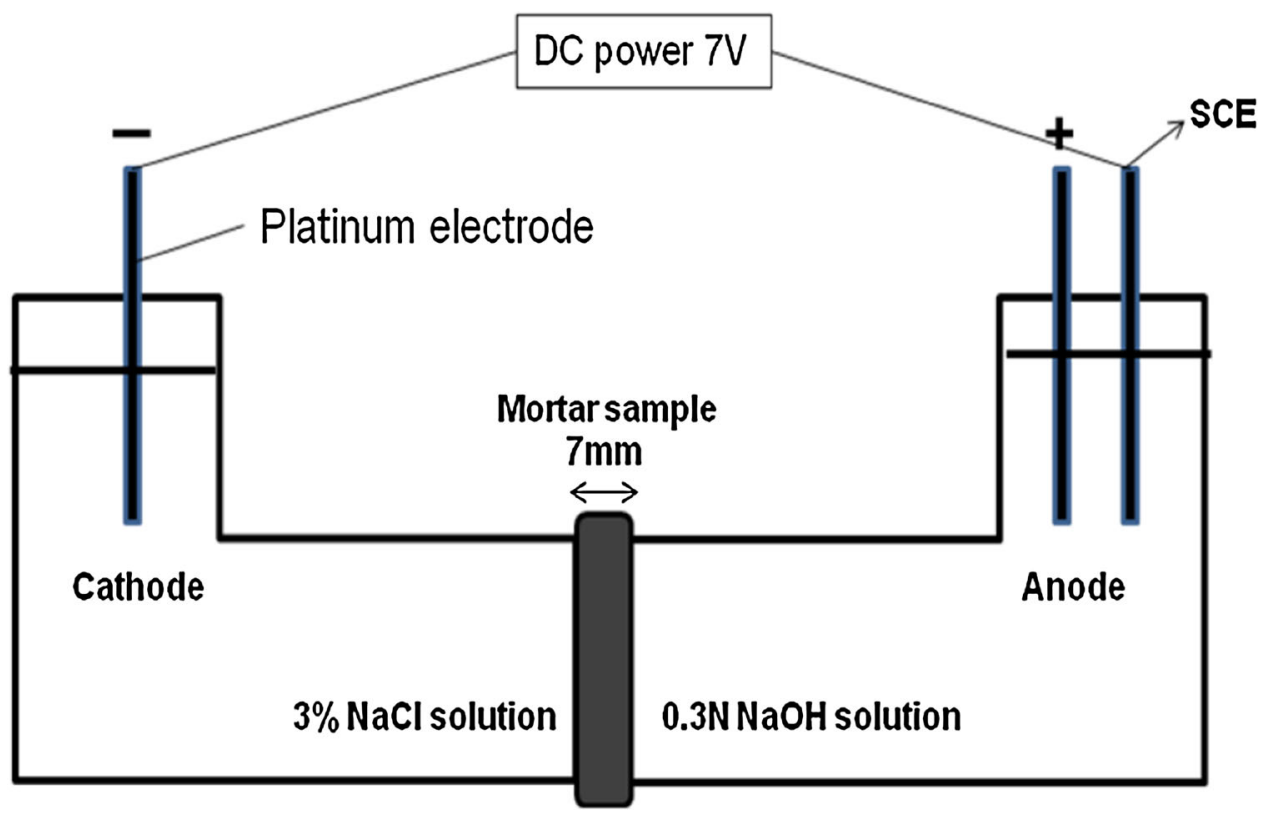

Fig. 2 Schematic diagram of experimental setup used for accelerated electromigration test.

between two glass cells. One of the cells was filled with $3 \%$ $\mathrm{NaCl}$ solution and the other cell with $0.3 \mathrm{~N} \mathrm{NaOH}$ solution as per ASTM C1202. Two platinum electrodes placed in both glass cells solution served as working electrodes whereas saturated calomel electrode (SCE) worked as reference electrode to monitor the potential applied. Once the mortar specimen disc, solutions and electrodes were in place, the potential voltage $7 \mathrm{~V}$ was applied and migration of chloride ions were measured periodically using UV-Vis spectrophotometer.

\section{Results and Discussions}

\subsection{Characterization of Nano-Silica}

Powdered silica nanoparticles were characterized using SEM, XRD and BET techniques. The SEM micrograph revealed that the average particle size of powdered-NS is $\sim 40 \mathrm{~nm}$ (Fig. 3a) and the particles are spherical, non- agglomerated and possess a smooth surface morphology. On the other hand the colloidal-NS appear in the form of agglomerates (Fig. 3b). From X-ray studies, the characteristic diffraction broad peak, centered on $22^{\circ}(2 \theta)$, confirmed its amorphous nature (Fig. 4). BET results shows that the specific surface area of powered-NS is $116.23 \mathrm{~m}^{2} / \mathrm{g}$.

\subsection{Effect of Nano-Silica on Gel/Space Ratio of Cement Mortar}

The Gel/space ratio is defined as the volume of gel divided by the sum of the volumes of gel and capillary pores (Power et al. 1948; Acker 2001) whereby "gel" is a synonym for hydration products which include the gel pores of typically $0.5-2.5 \mathrm{~nm}$. It is well-known that the compressive strength of cement based materials depends on the gel/space ratio (Pichler et al. 2013). For the Portland cement paste, it is assumed that $1 \mathrm{ml}$ of hydrated cement occupies $2.06 \mathrm{~mL}$ of space, the gel/space ratio is given by (Neville 1981) Eq. (3):
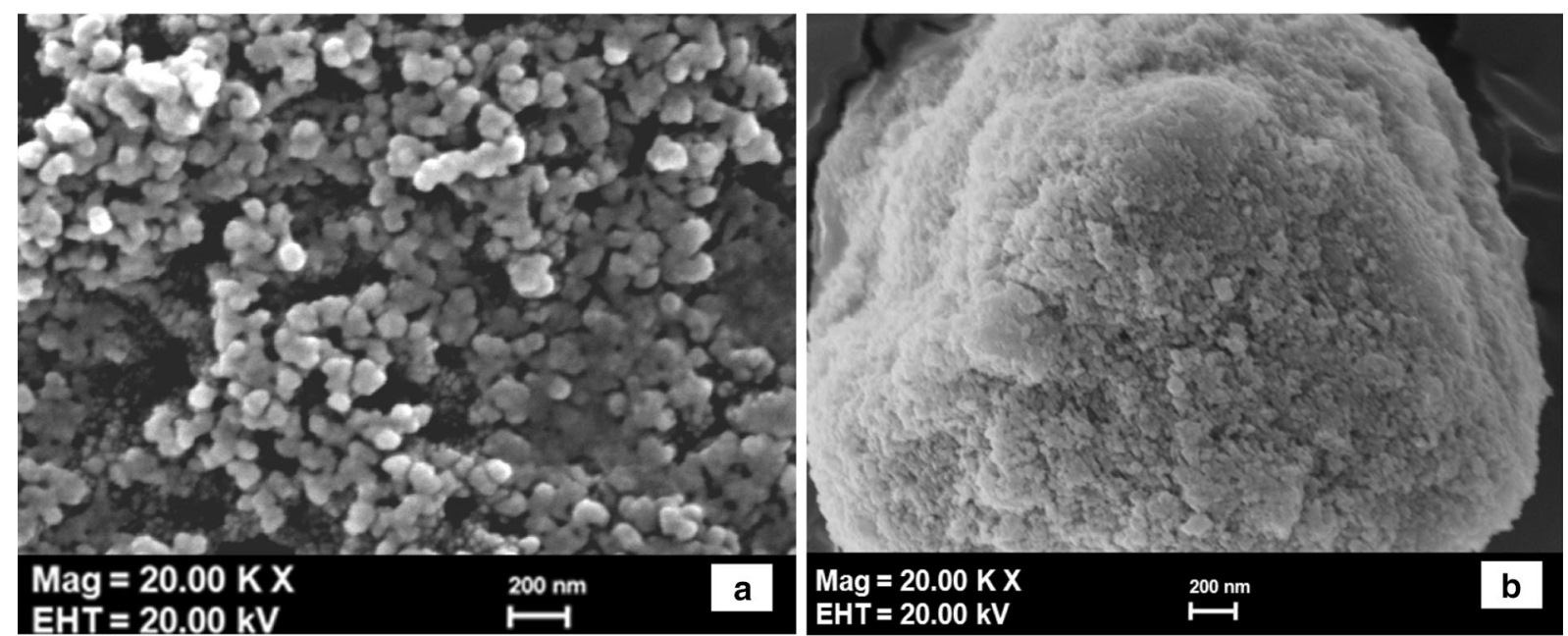

Fig. 3 SEM micrographs of a powdered-NS, b colloidal-NS. 


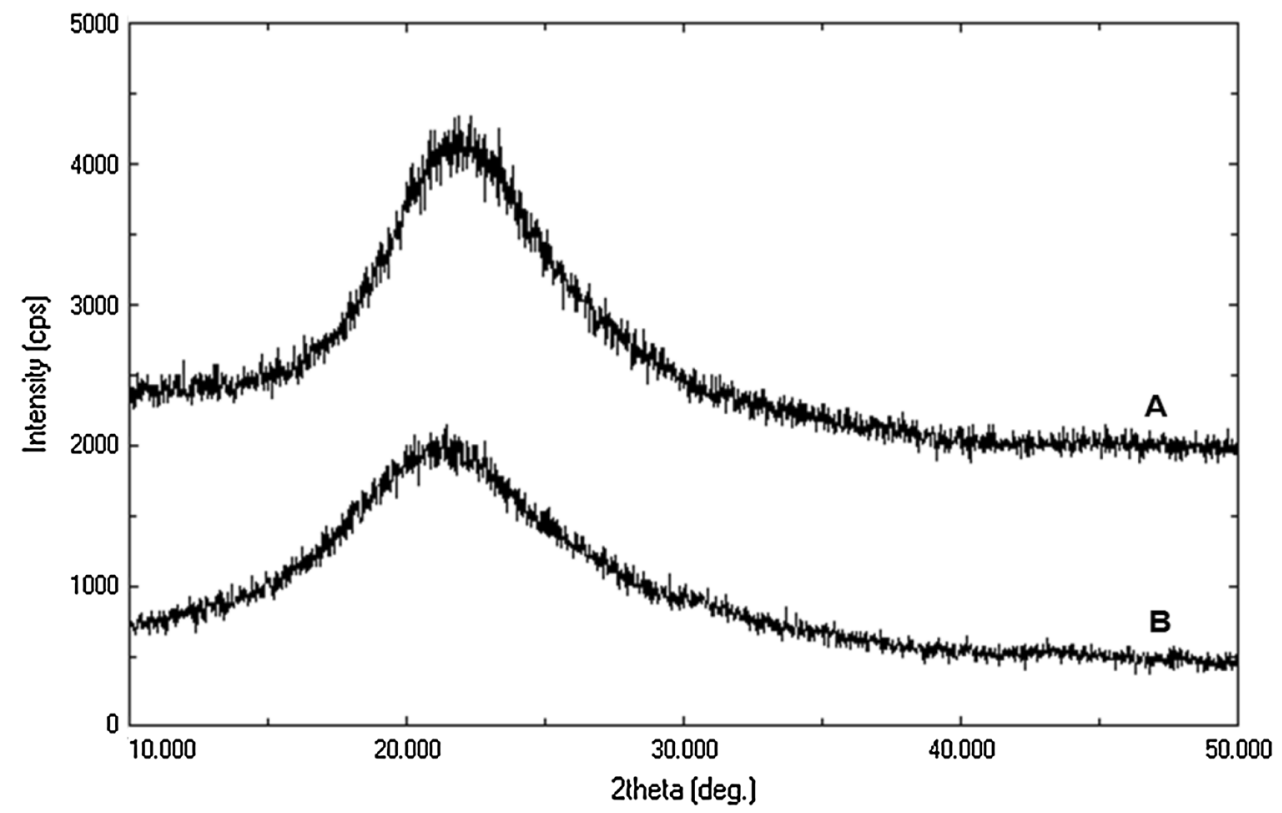

Fig. 4 XRD profile of $A$ colloidal-NS, $B$ powdered-NS.

Table 2 Calculated gel/space ratio of plain and blended cement mortar.

\begin{tabular}{c|c|c|c|c}
\hline Curing time (days) & Cement mortar & $3 \%$ SF & $3 \%$ powdered-NS & $3 \%$ colloidal-NS \\
\hline \hline 1 & 0.37 & 0.40 & 0.42 & 0.43 \\
\hline 3 & 0.47 & 0.49 & 0.63 & 0.53 \\
\hline 7 & 0.55 & 0.58 & 0.74 & 0.60 \\
\hline 28 & 0.71 & 0.74 & 0.94 & 0.76 \\
\hline
\end{tabular}

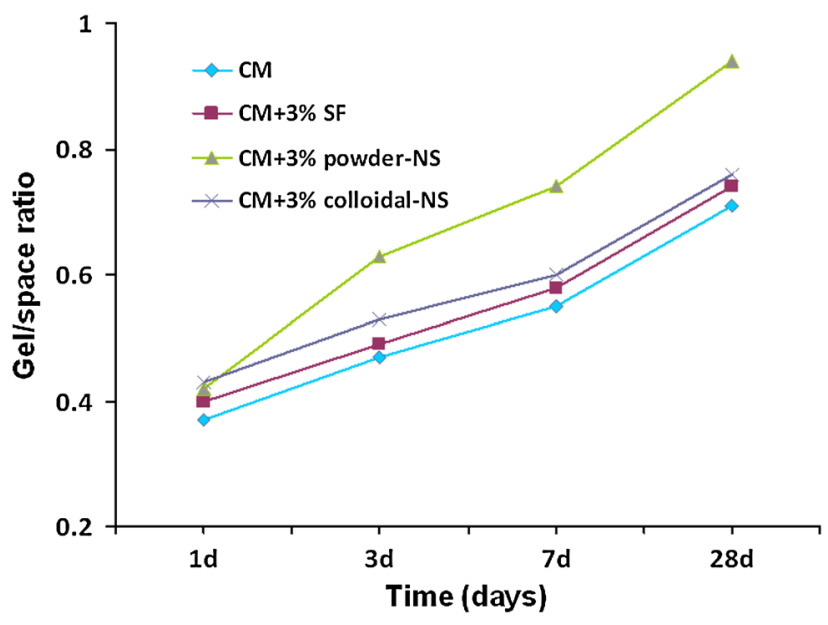

Fig. $5 \mathrm{Gel} / \mathrm{space}$ ratio with hydration time.

$$
X_{c}=\frac{2.06 V_{c} \propto_{c}}{V_{c} \propto_{c}+w / c}
$$

where $X_{c}$ is gel/space ratio of plain cement, $V_{c}$ is specific volume of anhydrous cement, $\alpha_{c}$ is degree of hydration of cement and $\mathrm{w} / \mathrm{c}$ is water-to-cement ratio. For supplementary materials (SF and NS) pozzolanic reaction, $1 \mathrm{~mL}$ of supplementary materials reacted is considered to occupy $2.52 \mathrm{~mL}$ of space (Lam et al. 2000), therefore, the gel/space ratio of blended cement is given by Eq. (4):

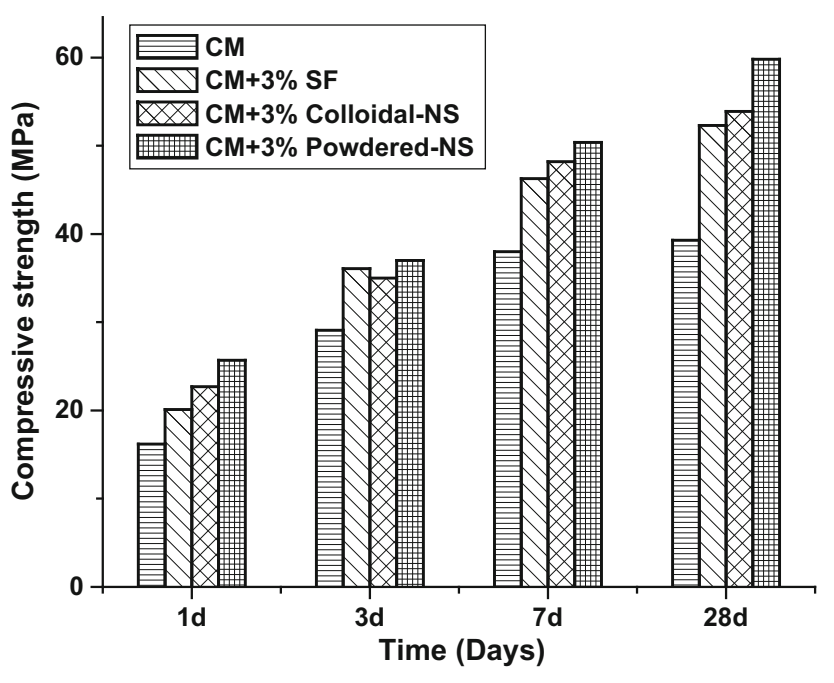

Fig. 6 Compressive strength of cement mortar with additives.

$$
X_{b c}=\frac{2.06 V_{c} \propto_{c} \mathrm{C}+2.5 V_{s} \propto_{s} \mathrm{~S}}{V_{c} \propto_{c} \mathrm{C}+V_{s} \propto_{s} \mathrm{~S}+\mathrm{W} / \mathrm{c}}
$$

where $X_{\mathrm{bc}}$ is gel/space ratio of blended cement; $V_{c}$ and $V_{s}$ are specific volumes; $\alpha_{c}$ and $\alpha_{s}$ are the degrees of hydration of cement and with the addition of supplementary materials (SF and NS), respectively, $\mathrm{C}$ and $\mathrm{S}$ are the original fractions of cement and SF, NS in blend. 

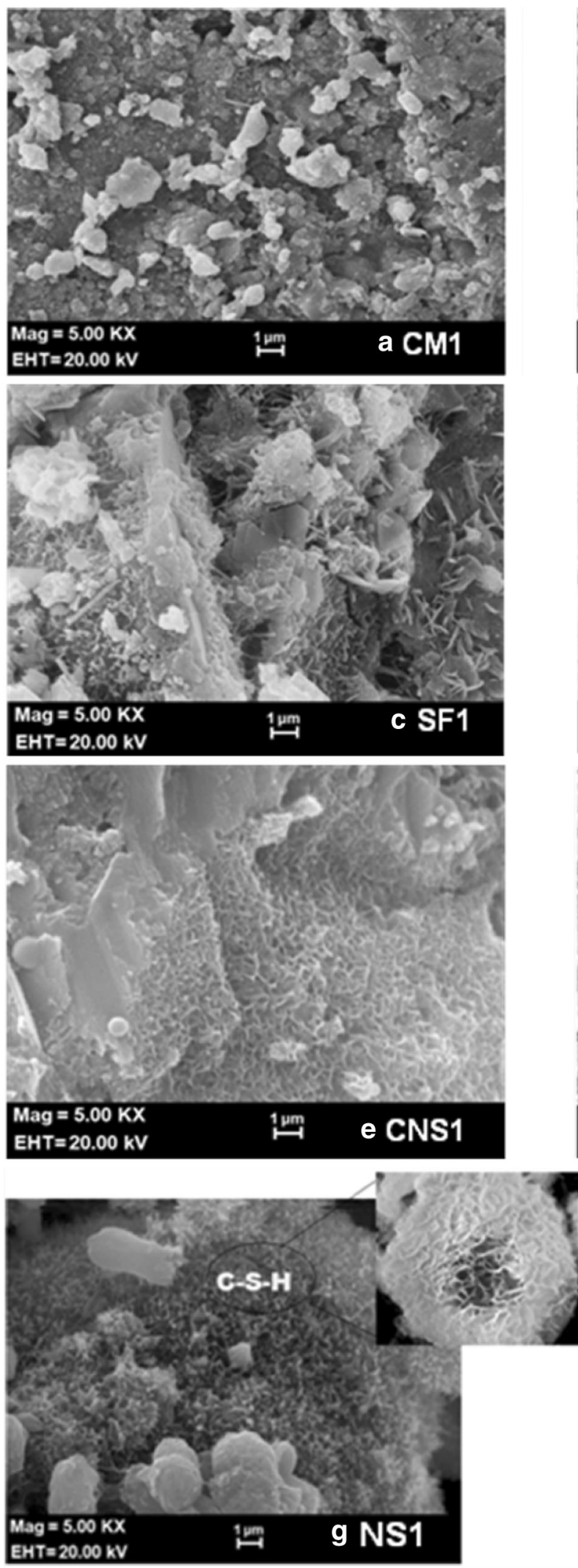


\section{EHT $=20.00 \mathrm{kV}$}



Fig. 7 SEM micrographs at $1 \& 28$ of hydration of $\mathbf{a}, \mathbf{b}$ plain cement mortar, $\mathbf{c}, \mathbf{d}$ with SF, e, $\mathbf{f}$ with colloidal-NS, and $\mathbf{g}, \mathbf{h}$ with powered-NS.

With the addition of powdered-NS ( $3 \%$ ), gel space ratio increases from 0.43 to 0.94 , while with colloidal-NS (3\%) $0.42-0.74$ from 1 to 28 days (Table 2). This result reveals that powdered-NS is more reactive and homogeneously mixed with cement matrix than that colloidal-NS (Fig. 5).
The continuous increasing trend of gel/space ratio signifies that the powder nano-silica act as a centre of nucleation for cement hydrates, which accelerate the hydration. The mechanism is related to the non-agglomerated nature (welldispersed particles) and high surface area of powdered-NS, 


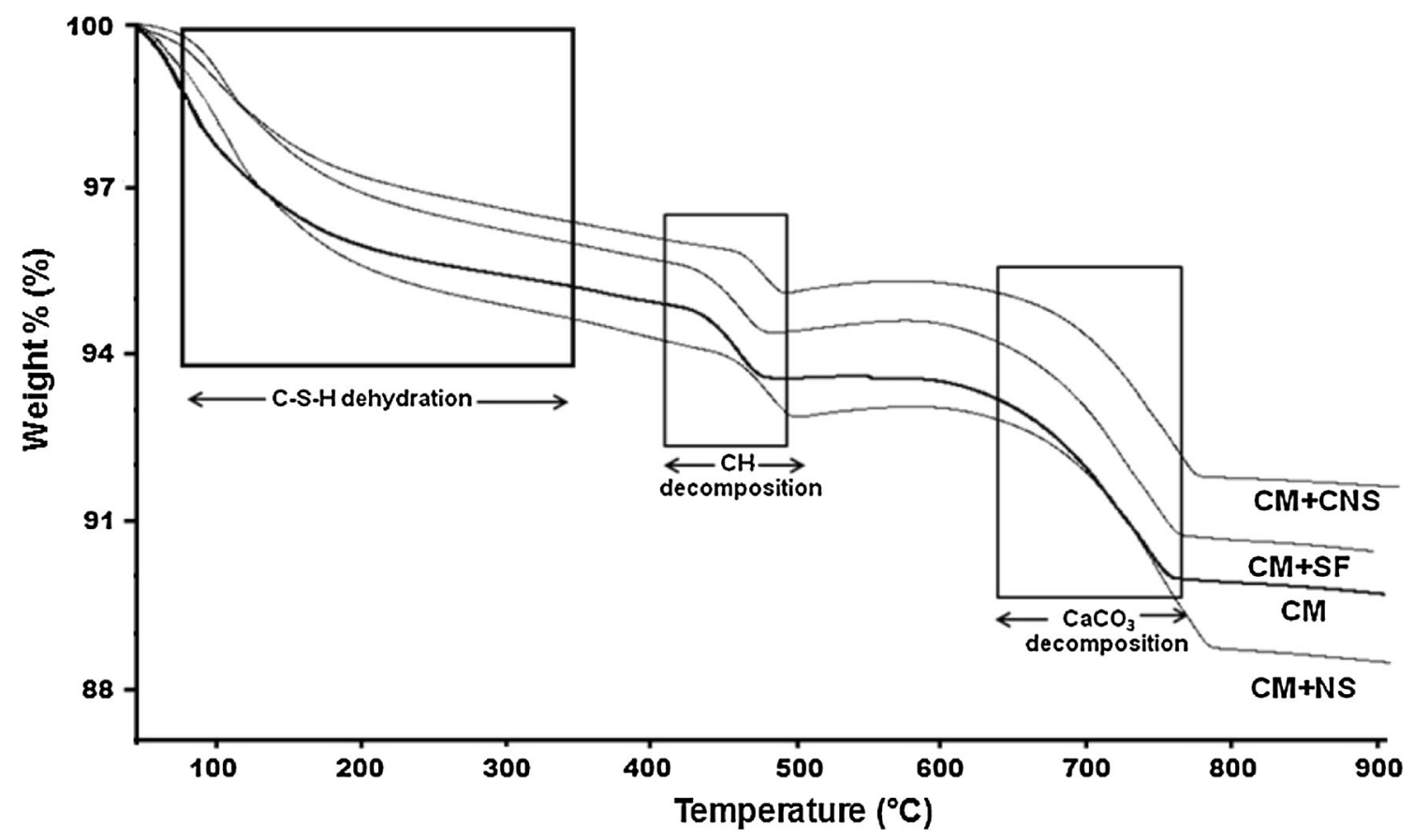

Fig. 8 TGA curve of cement mortar with NS and SF.

which works as a nucleation site for the precipitation of additional C-S-H gel. The formation of additional C-S-H occupies the available space leading to denser structure.

\subsection{Effect of Nano-Silica on Compressive Strength of Cement Mortar}

The modification on the cement hydration caused by nanoparticles can be reflected by their effect on the mechanical properties of cementitious materials. The addition of silica fume and nano-silica significantly improves the compressive strength with the increase of doses due to pozzolanic reaction. Figure 6 illustrates that the strength of the cement mortar with $1 \%$ powdered-NS increases by 19 and $17 \%$ at 1 and 3 day, respectively, whereas those with $1 \%$ colloidal-NS were increased $15 \%$ compared to those of the plain cement mortar. However, the strength gain of $1 \%$ powdered-NS at 28 days is $26 \%$ more than the control.

In addition, with $3 \%$ powdered-NS the strength goes to $37 \%$ higher than that the plain cement mortar at 1 day and $34 \%$ at 28 days. In contrast, with the colloidal-NS (3\%) strength gain is $28 \%$ at 1 day and $27 \%$ at 28 days. On the other hand, SF (3\%) is able to increase compressive strength $19 \%$ at 1 day and $25 \%$ at 28 days. From these results it may be inferred that SF shows its reactivity at later stage of hydration (Fig. 6). The development of compressive strength with and without NS and SF were expressed as a function of gel/space ratio. The result signifies that the gel/ space ratio increases with curing time. A significant increase in strength compared with the control was also observed. This may be attributed to higher content of calcium silicate hydrate $(\mathrm{C}-\mathrm{S}-\mathrm{H})$ in NS and SF blended specimens, due to the pozzolanic reaction of $\mathrm{CH}$ produced from cement hydration with nano-silica and silica fume. These results are further supported by microstructure studies of cement mortar at 28 days of hydration (Fig. 7). The SEM micrographs revealed that with the addition of nano-silica, more $\mathrm{C}-\mathrm{S}-\mathrm{H}$ is appearing at the early stage of hydration, so that later on the microstructure at 28 days become more compacted, uniform and denser. This mechanism emphasise that the addition of powdered-NS increases the strength at the early stage, mainly because of packing effect. It actually acted as filler material, which filled the interstitial spaces and pores, inside the matrix of hardened cement mortar, resulting into increase in density as well as its strength.

\subsection{Portlandite Quantification}

The TG/DTG curves showed that the typical reactions occurring in cement matrix when subjected to a progressive temperature rise from room temperature to $1000{ }^{\circ} \mathrm{C}$ in $200 \mathrm{~mL} / \mathrm{min}$ Nitrogen gas flow. The first change was observed between 60 and $105{ }^{\circ} \mathrm{C}$, can be attributed to the departure of weekly bound water (Fig. 8). The second significant loss between $\sim 120-400{ }^{\circ} \mathrm{C}$ corresponding to dehydration of some hydrates like $\mathrm{C}-\mathrm{S}-\mathrm{H}$ and ettringite (Gabrovsek et al. 2006; Ramachandran et al. 2003). The third reduction at $\sim 400-500{ }^{\circ} \mathrm{C}$, causes a loss in mass corresponding to de-hydration of $\mathrm{CH}$; hence, the portlandite decomposes into free lime (dehydroxylation) (Gaitero et al. 2008; Jain and Neithalath 2009). Subsequently, the final weight loss area was observed at $\sim 650-800{ }^{\circ} \mathrm{C}$, occurs due to the decomposition of calcium carbonate (Alonso and Fernandez 2004; Gabrovsek et al. 2006). Figure 9a showed a strong decrease in the $\mathrm{CH}$ peak, appears considerably smaller with $3 \%$ powdered NS than the same peak of other samples at 1 day (Table 3 ). As well as the hydration proceeds up to 28 days, the reduction in this region $(\sim 400-500)$ is observed significantly more with powdered NS ( $\sim 68 \%$ ). Similarly, colloidal-NS and SF reduce $\sim 57$ and $31 \%$ at 28 days, respectively (Fig. $9 \mathrm{~b}$ ). The pozzolanic reaction with $\mathrm{CH}$ is proportional to the amount of surface 

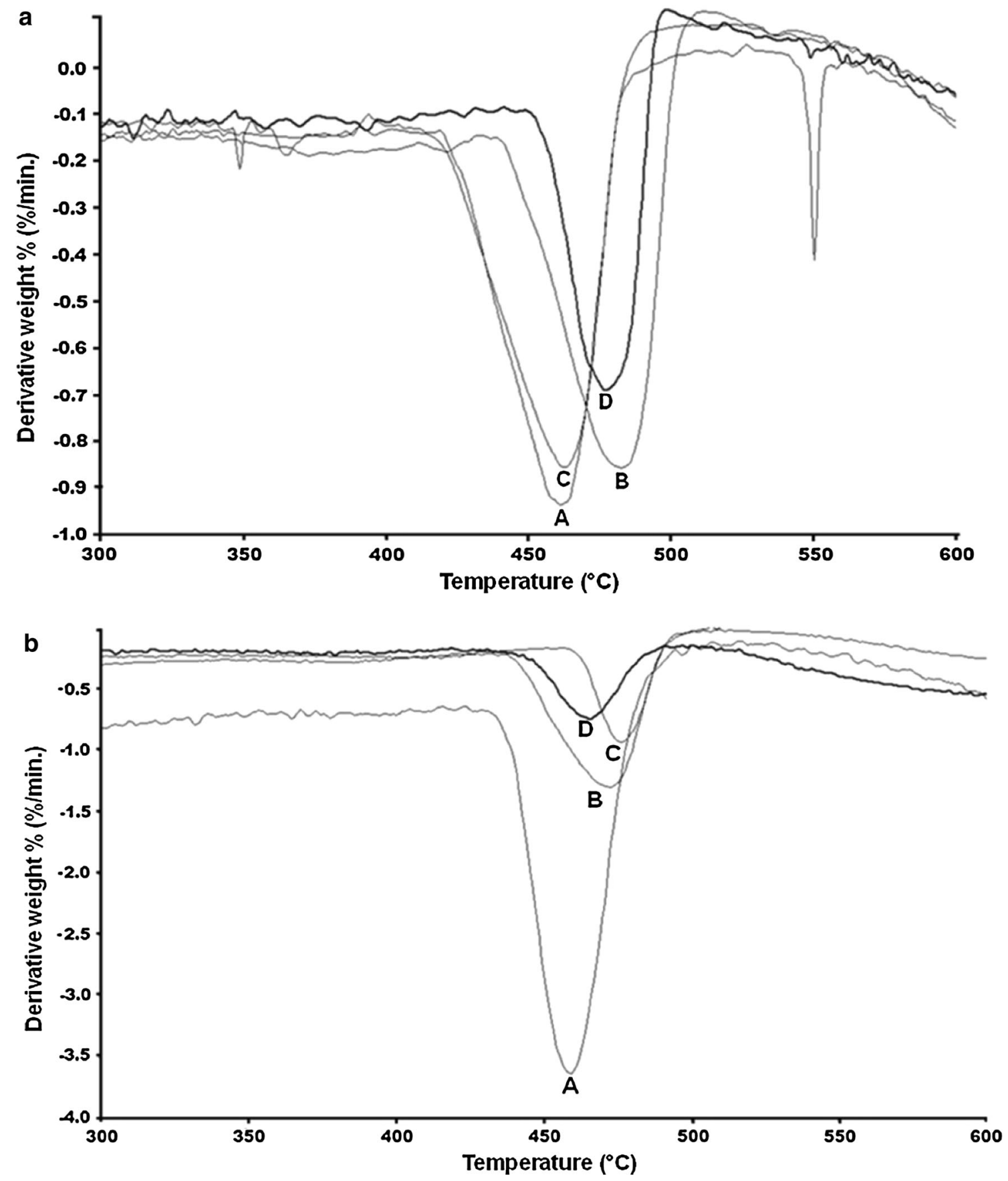

Fig. 9 a DTG of samples at 1 day. $A$ plain cement mortar, $B \mathrm{CM}+3 \% \mathrm{SF}, C \mathrm{CM}+3 \% \mathrm{CNS}$, and $D \mathrm{CM}+3 \% \mathrm{NS}$. b DTG of samples at 28 day. $A$ plain cement mortar, $B \mathrm{CM}+3 \% \mathrm{SF}, C \mathrm{CM}+3 \% \mathrm{CNS}$, and $D \mathrm{CM}+3 \% \mathrm{NS}$.

Table 3 Portlandite content in cement mortar incorporated nanosilica.

\begin{tabular}{c|c|c|c|c}
\hline \multirow{2}{*}{ Sample } & \multicolumn{4}{|c}{ Portlandite content (\%) } \\
\cline { 2 - 5 } & 1 days & 3 days & 7 days & 15 days \\
\hline \hline Cement mortar & 5.85 & 9.25 & 11.6 & 10.32 \\
\hline $\mathrm{CM}+3 \% \mathrm{SF}$ & 5.38 & 6.9 & 7.55 & 6.5 \\
\hline $\mathrm{CM}+3 \%$ colloidal-NS & 4.2 & 6.3 & 6.7 & 4.8 \\
\hline $\mathrm{CM}+3 \%$ powder-NS & 4.0 & 5.8 & 5.4 & \\
\hline
\end{tabular}




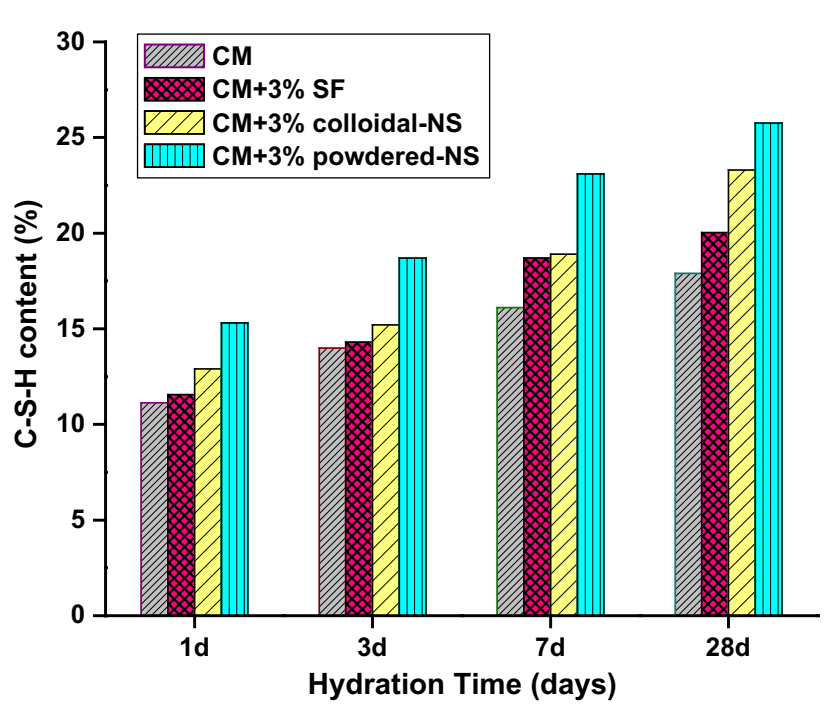

Fig. $10 \mathrm{C}-\mathrm{S}-\mathrm{H}$ content in plain and nano-silica incorporated cement mortar.

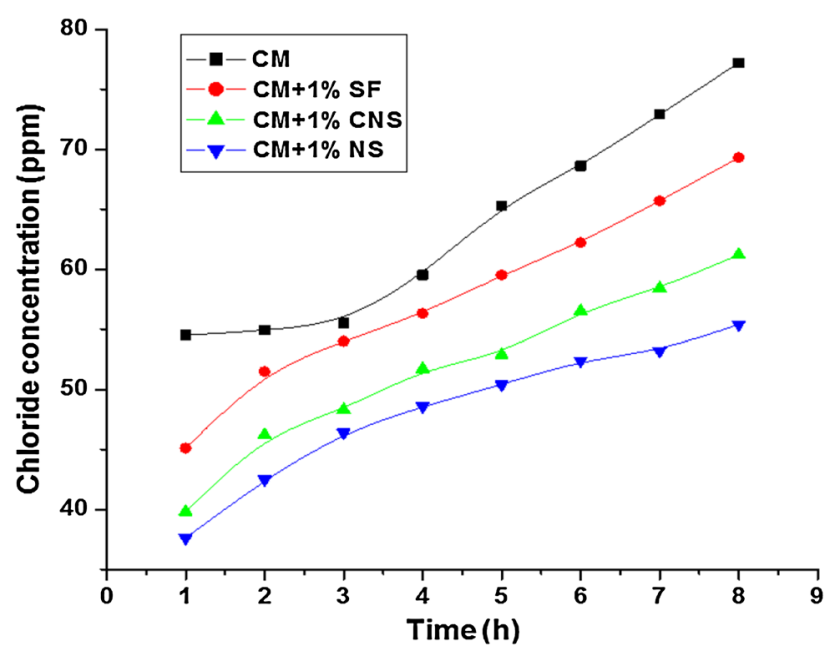

Fig. 11 Concentration of chloride ion with $1 \%$ additives.

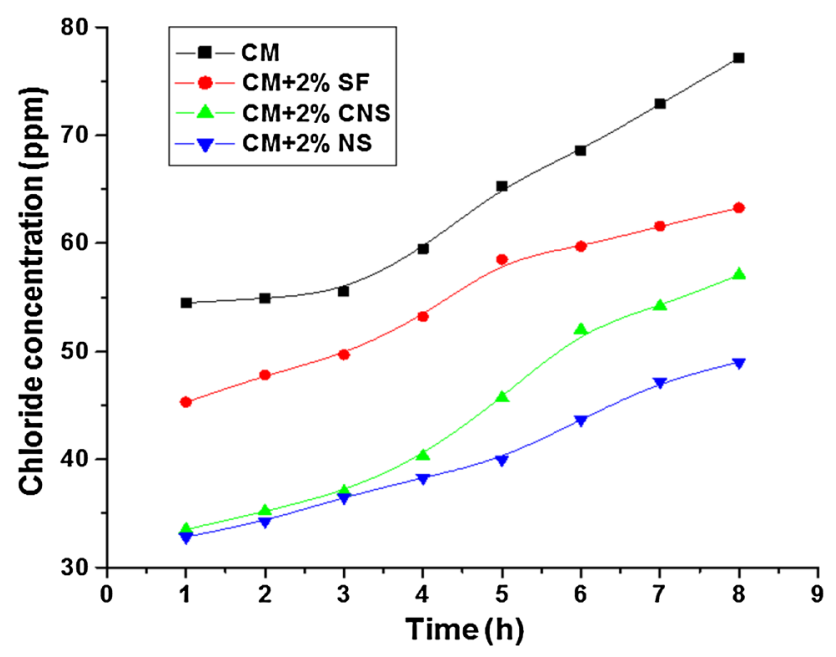

Fig. 12 Concentration of chloride ion with $2 \%$ additives.

area available for the reaction. The results reveal that the powered-NS has non-agglomerated particles which allow the formation of additional $\mathrm{C}-\mathrm{S}-\mathrm{H}$ on their surface by

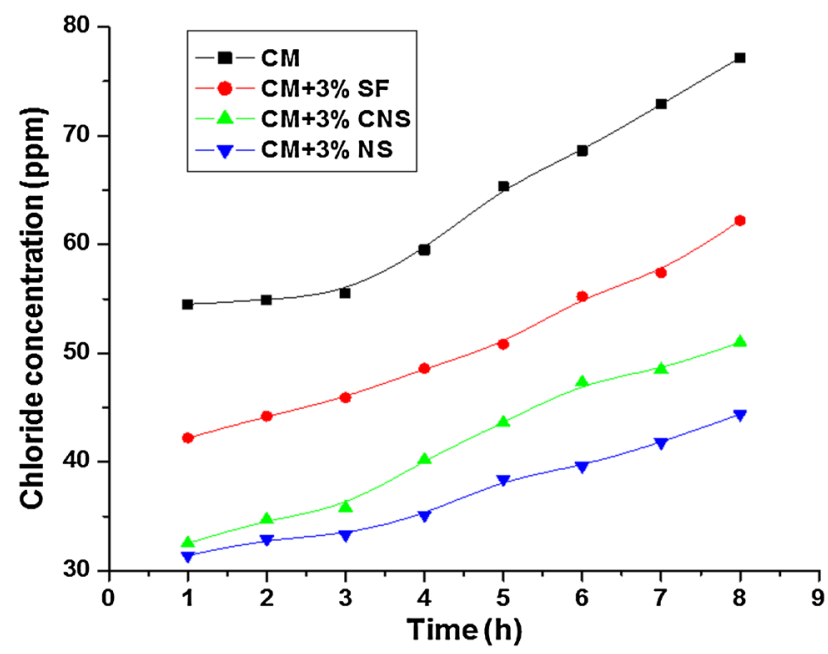

Fig. 13 Concentration of chloride ion with $3 \%$ additives.

consuming $\mathrm{CH}$. Hence, the pozzolanic reactivity of powdered-NS is observed to be higher than colloidal-NS and SF.

\subsection{C-S-H Quantification}

A detailed approach is given in this section to quantify the $\mathrm{C}-\mathrm{S}-\mathrm{H}$ through TG/DTG. The composition of $\mathrm{C}-\mathrm{S}-\mathrm{H}$ gel approximately $1.7 \mathrm{CaO} \cdot \mathrm{SiO}_{2} \cdot 4 \mathrm{H}_{2} \mathrm{O}$ for saturated $\mathrm{C}_{3} \mathrm{~S}$ pastes as well as cement, where 4 mol of water including adsorbed water on the surface of hydration products, will be removed at temperature below $110{ }^{\circ} \mathrm{C}$ (Taylor 1997). Therefore, the equilibrium composition of $\mathrm{C}-\mathrm{S}-\mathrm{H}$ becomes $1.7 \mathrm{CaO} \cdot \mathrm{SiO}_{2} \cdot 2 \cdot 1 \mathrm{H}_{2} \mathrm{O}$. Similarly in the present study, the formation of $\mathrm{C}-\mathrm{S}-\mathrm{H}$ with chemical composition $11.7 \mathrm{CaO} \cdot \mathrm{SiO}_{2} \cdot 2.1 \mathrm{H}_{2} \mathrm{O}$ was considered (Young and Hansen 1987). The results indicate that the C-S-H formation at 1 day with plain cement mortar, colloidal nano-silica and powder nano-silica is $11.3,12.9$ and $15.3 \%$, respectively.

Further, at 28 days, powdered-NS enhances the $\mathrm{C}-\mathrm{S}-\mathrm{H}$ content approx $30 \%$ higher than that plain cement mortar, whereas the colloidal-NS increased approx $21 \%$ (Fig. 10). The mechanism of significant increase in $\mathrm{C}-\mathrm{S}-\mathrm{H}$ content with powdered-NS, colloidal-NS, SF as compared to cement mortar is due to high surface area, resulting to the deposition of cement hydration products on them. The pozzolanic reactivity of powdered-NS is observed to be higher causing continuous consumption of $\mathrm{CH}$ to form additional $\mathrm{C}-\mathrm{S}-\mathrm{H}$ from the early stage of hydration. The results are consistent with $\mathrm{CH}$ reduction. The non-agglomerated nature of NS, allow it to mix with cement grains homogeneously and develop more compact and denser $\mathrm{C}-\mathrm{S}-\mathrm{H}$. This agrees with the remarkable increase in the compressive strength when powdered NS particles are incorporated into cement matrix.

\subsection{Chloride Penetration Resistance}

The electromigration test shows that the cement mortar incorporating nano-silica resist the chloride ingress of mortar, as indicated by the reduced chloride ion concentration with increasing doses of nano-silica and SF. Such improvements are significant with powdered-NS. At $7 \mathrm{~V}$ the chloride ion concentration drops to $\sim 28 \%$ with $1 \%$ nano- 
silica, whereas with colloidal-NS $\sim 20 \%$ only at $8 \mathrm{~h}$, results are illustrated in Fig. 11. As the percentage addition of NS and SF increases up to $3 \%$, the ingress of chloride ions in destination solution $(0.3 \mathrm{~N} \mathrm{NaOH})$ through mortar specimen reduces by 43,34 and $19 \%$ in powdered-NS, colloidal-NS and SF, respectively. It was observed that the penetration of mortar specimen decreases (Figs. 12 and 13). The mechanism interpreted that the presence of powdered-NS contribute more in the reduction of chloride ions ingress as compared to colloidal-NS, because powdered-NS is non-agglomerated in nature, which increases the packing density of solid materials by occupying space between cement grains. These physical effects of powered-NS may contribute to refine the pore system and reduce the chloride penetration of microstructure of hydration products. These findings are also consistent with gel/space ratio. The colloidal-NS is agglomerated, does not mix evenly with cement mortar and develop weak zone, which are favourable for migration of ionic species. The electromigration test reveals that the small amount of nano-silica markedly improves the chloride penetration resistance of the cement mortars. Finally, it can be concluded that non-agglomerated powdered-NS can be used to improve cement and concrete durability.

\section{Conclusions}

Based on the experimental results presented in this study, the following conclusions can be drawn:

(1) The dispersibility of nanomaterials plays a key role, therefore spherical and non-agglomerated nano-silica was prepared to address the issue of mixing of nanomaterials into cement matrix. It is found that non-agglomerated powdered-NS is effective in improving the mechanical properties of cement mortar.

(2) The improvement in compressive strength and gel/ space ratio of hardened mortar adding powered-NS is greater than that colloidal-NS which was associated with the higher content of $\mathrm{C}-\mathrm{S}-\mathrm{H}(30 \%)$, leading to more compacted and denser microstructure.

(3) Powdered-NS due to higher pozzolanic reactivity reduced $\mathrm{CH}$ content up to $68 \%$, while colloidal-NS reduced $57 \%$ at 28 days of hydration.

(4) SEM micrographs revealed that the powdered-NS behaved as a filler to improve cement microstructure leading to denser morphology.

(5) For durability assessment, chloride ingress was also monitored in cement mortar with powered-NS, colloidal-NS and SF. Among these Powdered-NS reduced the chloride ion concentration up to $\sim 43 \%$ as compared to plain cement mortar.

\section{Open Access}

This article is distributed under the terms of the Creative Commons Attribution License which permits any use, distribution, and reproduction in any medium, provided the original author(s) and the source are credited.

\section{References}

Acker P. (2001). Micromechanical analysis of creep and shrinkage mechanisms. In F. J. Ulm, Z. P. Bazant, F. H. Wittmann (Eds.), Creep, shrinkage and durability mechanics of concrete and other quasi-brittle materials, 6th international conference (pp. 15-26) Amsterdam, Netherlands: CONCREEP@MIT Elsevier.

Alonso, C., \& Fernandez, L. (2004). Dehydration and rehydration processes of cement paste exposed to high temperature environments. Journal of Materials Science, 39(9), 3015-3024.

Baykal, M. (2000). Implementation of durability models for portland cement concrete into performance-based specifications. Austin, TX: University of Texas at Austin.

Bjornström, J., Martinelli, A., Matic, A., Borjesson, L., \& Panas, I. (2004). Accelerating effects of colloidal nanosilica for beneficial calcium-silicate-hydrate formation in cement. Chemical Physics Letters, 392(1-3), 242-248.

Coenen, S., \& Kruif, C. G. (1988). Synthesis and growth of colloidal silica particles. Journal of Colloid and Interface Science, 124(1), 104-110.

Flores, I., Sobolev K., Torres-Martinez L. M., Cuellar E. L., Valdez P. L., Zarazua E. (2010). Performances of cement systems with nano- $\mathrm{SiO}_{2}$ particles produced by using the sol-gel method. In Transportation Research Record: Journal of the Transportation Research Board, No. 2141 (pp. 10-14). Washington, DC: Transportation Research Board of the National Academies.

Gabrovsek, R., Vuk, T., \& Kaucic, V. (2006). Evaluation of the hydration of Portland cement containing various carbonates by means of thermal analysis. Acta Chimica Slovenica, 53(2), 159-165.

Gaitero, J. J., Campillo, I., \& Guerrero, A. (2008). Reduction of the calcium leaching rate of cement paste by addition of silica nanoparticles. Cement and Concrete Research, 38(8-9), 1112-1118.

Gaitero, J. J., Zhu, W., \& Campillo, I. (2009). Multi-scale study of calcium leaching in cement pastes with silica nanoparticles. Nanotechnology in construction 3, Berlin (pp. 193-198). Heidelberg, Germany: Springer.

Gallucci, E., Zhang, X., \& Scrivener, K. L. (2013). Effect of temperature on the microstructure of calcium silicate hydrate (C-S-H). Cement and Concrete Research, 53, 185-195.

He, X., \& Shi, X. (2008). Chloride permeability and microstructure of Portland cement mortars incorporating nanomaterials. Transportation Research Record: Journal of the Transportation Research Board, 2070, 13-21.

Hou, P., Cheng, X., Qian, J., \& Shah, S. P. (2014). Effects and mechanisms of surface treatment of hardened cement-based materials with colloidal nano- $\mathrm{SiO}_{2}$ and its precursor. Construction and Building Materials, 53, 66-73. 
Jain, J., \& Neithalath, N. (2009). Analysis of calcium leaching behavior of plain and modified cement pastes in pure water. Cement and Concrete Composite, 31(3), 176-185.

Ji, T. (2005). Preliminary study on the water permeability and microstructure of concrete incorporating nano- $\mathrm{SiO}_{2}$. Cement and Concrete Research, 35(10), 1943-1947.

Jo, B., Kim, C., \& Lim, J. (2007). Characteristics of cement mortar with nano-SiO 2 particles. Construction and Building Materials, 21(6), 1351-1355.

Kong, D., Su, Y., Xi, D., Yang, Y., Wei, S., \& Shah, S. P. (2013). Influence of nano-silica agglomeration on fresh properties of cement pastes. Construction and Building Materials, 43, 557-562.

Kontoleontos, F., Tsakiridis, P. E., Marinos, A., Kaloidas, V., \& Katsioti, M. (2012). Influence of colloidal nano-silica on ultrafine cement hydration: Physicochemical and microstructural characterization. Construction and Building Materials, 35, 347-360.

Lam, L., Wong, Y. L., \& Poon, C. S. (2000). Degree of hydration and gel/space ratio of high-volume fly ash/cement systems. Cement and Concrete Research, 30(5), 747-756.

Lin, W. T., Huang, R., Chang, J. J., \& Lee, C. L. (2009). Effect of silica fume on the permeability of fiber cement composites. Journal of the Chinese Institute of Engineers, 32(4), 531-541.

Neville, A. M. (1981). Properties of concrete (3rd ed., pp. 257-279). London, UK: ELBS with Longman.

Olsona, R. A., \& Jennings, H. M. (2001). Estimation of C-S-H content in a blended cement paste using water adsorption. Cement and Concrete Research, 31(3), 351-356.

Pichler, B., Hellmich, C., Eberhardsteiner, J., Wasserbauer, J., Termkhajornkit, P., Barbarulo, R., \& Chanvillard, G. (2013). Effect of gel-space ratio and microstructure on strength of hydrating cementitious materials: An engineering micromechanics approach. Cement and Concrete Research, 45, 55-68.

Powers, T. C., \& Brownyard, T. L. (1948). Studies of the physical properties of hardened Portland cement paste. Research Laboratories of the Portland Cement Association Bulletin, 22, 101-992.

Quercia, G., Spiesz, P., Hüsken, G., \& Brouwers, H. J. H. (2014). SCC modification by use of amorphous nano-silica. Cement \& Concrete Composites, 45, 69-81.
Ramachandran, V. S., Paroli, R. M., Beaudoin, J. J., \& Delgado, A. H. (Eds.). (2003). Handbook of thermal analysis of construction materials. Norwich: Noyes Publications.

Sanchez, F., \& Sobolev, K. (2010). Nanotechnology in concrete-A review. Construction and Building Materials, 24(11), 2060-2071.

Savas B. Z. (2000). Effects of microstructure on durability of concrete, Ph.D. thesis. Raleigh: North Carolina State University.

Shi, X., Xie, N., Fortune, K., \& Gong, J. (2012). Durability of steel reinforced concrete in chloride environments: An overview. Construction and Building Materials, 30, 125-138.

Singh, L. P., Bhattacharyya, S. K., \& Ahalawat, S. (2012a). Preparation of size controlled silica nano particles and its functional role in cementitious system. Journal of $\mathrm{Ad}$ vanced Concrete Technology, 10(11), 345-352.

Singh, L. P., Bhattacharyya, S. K., Mishra, G., \& Ahalawat, S. (2012b). Reduction of calcium leaching in cement hydration process using nanomaterials. Materials Technology, 27(3), 233-238.

Singh, L. P., Karade, S. R., Bhattacharyya, S. K., \& Ahalawat, S. (2013). Beneficial role of nano-silica in cement based materials - a review. Construction and Building Materials, 47, 1069-1077.

Tan, B., Lehmler, H. J., Vyas, S. M., Knuston, B. L., \& Rankin, S. E. (2005). Controlling nanopore size and shape by fluorosurfactant templating of silica. Chemistry of Materials, 17(4), 916-925.

Taylor, H. F. W. (1997). Cement chemistry. London, UK: Thomas Telford.

Toutanji, H., Delatte, N., \& Aggoun, S. (2004). Effect of supplementary cementitious materials on the compressive strength and durability of short-term cured concrete. Cement and Concrete Research, 34(2), 311-319.

Venkatathri, N., \& Nanjundan, S. (2009). Synthesis and characterization of a mesoporous silica microsphere from polystyrene. Materials Chemistry and Physics, 113(2-3), 933-936.

Young, J. F., \& Hansen, W. (1987). Volume relationships for $\mathrm{C}-\mathrm{S}-\mathrm{H}$ formation based on hydration stoichiometries. $\mathrm{Ma}$ terials Research Society, 85, 313. 